\title{
FUNDING STRATEGIES: SURVIVING IMPERIAL INTENTIONS, PROTEAN POLICIES AND RUTHLESS REALITY
}

Paper presented at the ASASWEI conference held at Stellenbosch on 6/7 September 2005

\section{A de V Smit}

\section{INTRODUCTION}

William Bolitho [Twelve Against the Gods, 'Lola Montez'] enchantingly stated that "You need more tact in the dangerous act of giving...than in any other social action." The act of giving funds in the welfare world is hazardous and sadly, many of our welfare mandarins eschew tact - some even think 'tact' is an acronym for some technical application.

Raising money is an arduous and effort-intensive activity. Finance is the cornerstone that underpins all welfare services and for decades now a surfeit of both finance and services has eluded this sector. All funding bodies have certain criteria on which they base their allocations but in many cases these are vague, not accurately determined in terms of service needs and organisational performance and are open to influence. Against this backdrop an extensive study based at the oldest funding agency of its kind, the Community Chest of the Western Cape, was embarked upon to improve financial resource allocation decision-making.

In order to analyse service needs and funding patterns more accurately, two data bases were established to house data gathered from beneficiary organisations of the Community Chest. The first has captured a wide variety of organisation-related information (financial, service and staffing) over a six year period and the second has accommodated data garnered from a survey of such beneficiary organisations. While the databases are interactive, the contents of this paper will primarily present a select synopsis of the more salient findings of the survey and a perfunctory review of the country's funding policies. As such, it includes a brief description of the research methodology, a glimpse at funding policies and a succinct profile of the organisations surveyed. Concerns related to sustainability and development are raised. Further, findings on funding strategies and funding sources are also presented. Possible options to improve funding are pithily mentioned and in conclusion, suggestions are made on how to overcome the parlous state of welfare funding as evidenced by the survey and other findings.

\section{SURVEY METHODOLOGY}

The population of beneficiary organisations that had been awarded a grant for the financial year 2004/5 by September 2004 by the Community Chest, constituted the sample. This numbered 376 organisations. These included all fields of service that the Community Chest funded except for a few organisations that constituted the HIV/AIDS category whose applications had not been finalised by that date.

All organisations were mailed a survey questionnaire with instructions and a self- addressed envelope by 1 November 2004. Of the 367 organisations that were sent a questionnaire, 232 or $62 \%$ beneficiary organisations (or respondents) replied by the due date. This is a large sample and represents a wide range of welfare/NGO-type organisations operating throughout the Western Cape Province.

The survey questionnaire sought information in various categories: details of those that submitted funding applications and persons in charge of the organisations, the Community Chest fund application process, accounting practices, development and sustainability, project and operational 
funding, funding sources, one-stop funding, corporate governance, Provincial funding polices and perceptions of the Community Chest.

A database was created with links to the previously developed organisation database thus allowing far greater permutation of data analysis. Once captured in the survey database the information was analysed using Statistica and Excel. It should be noted that total response rates varied per item and thus response rates and percentages are based on these varying totals.

\section{INTENTIONS AND POLICIES}

South Africa's welfare mandarins have been running for decades. But, as the queen in Lewis Carroll's Through the Looking-Glass II said, "A slow sort of country ... Now, here, you see, it takes all the running you can do, to keep in the same place. If you want to get somewhere else, you must run at least twice as fast as that!" At issue, is thus the fitness of our welfare mandarins!

According to Winckler (1969:31), the first welfare provisions in South Africa were enacted some one hundred and fifty years ago in the Meesters en Dienstboden Wet, 1856 (Act 15 of 1856). Thereafter, a flurry of welfare related statutes were promulgated, particularly so subsequent to the Carnegie Commission of 1932. The South African welfare empire thus had an early start and has grown substantially over the years.

While various forms of poor relief were available towards the end of the $19^{\text {th }}$ Century, statutorily determined social benefit schemes began emerging from the 1920's (Winckler, 1969:98). The well-known welfare partnership between the state and the private sector that exists to-day had its origins in the Welfare Organisations Act, 1947 (Act 40 of 1947). Some nine years earlier in 1938, the first scheme to subsidise social workers was introduced by the Department of Social Welfare. It consisted of 75 percent of the salary costs of social workers in the private sector and local authorities (Martine, 1989:124). In 1966, this scheme was amended to include point-based criteria - size and nature of the caseload (Martine, 1989:126).

While $204(88 \%)$ organisations indicated that they received subsidies/funds from national/provincial government departments, only $161(70 \%)$ organisations indicated that they were familiar with current government funding policies. A staggering $188(90 \%)$ indicated that they did not receive sufficient funds from the government and of this number $91(48 \%)$ indicated that this was as a result of the bad current funding policy. Further, 158 (73\%) organisations felt that the existing government funding policies are inappropriate and $108(52 \%)$ organisations indicated that the funding polices were too complex. But what is the aetiology of this disgruntlement?

Over the years the central government had many intentions - they all attempted to prescribe more formalisation and control over all welfare activity in the country. The politics of the day substantially influence funding policies - the former government's race-based funding being known to all as is the current government's developmental approach to welfare. These intentions are chronicled in a number of enquiries, reports and policy documents. Of note, the Du Plessis Committee of Enquiry into the Financing of Voluntary Organisations reported on uniformity and determined roles of the respective partners (Martine, 1989:125).

The Committee to Establish a Norm for Social Work Posts reported in 1984 that the “...subsidy procedures are inadequate and unequivocally recommends that subsidies for social work posts be considered only in the context of an approved service programme" (McKendrick:1985:157). Based on this report and in anticipation of subsidies being determined on a programme plan basis rather than on the original social work post subsidisation formula, McKendrick wrote his seminal 
article on funding of programme proposals a good twenty years ago. The recommendations of the above-mentioned Committee formed the basis of the Formulation, Evaluation and Financing of Social Welfare Programmes issued in 1987. While advocating a programme plan subsidy scheme, it remained fairly restricted to professional social work activity (RSA, 1987:6).

In 1991 the enquiry into the Voluntary Welfare Initiative and the Financing of the Welfare System undertaken by the Working Committee of the South African Welfare Council and the Interdepartmental Consultative Committee on Social Welfare Matters also recommended funding on the basis of approved welfare programmes (RSA, 1991:70). This enquiry resulted in The Formulation, Evaluation and Financing of Social Welfare/Service Programmes - a more liberal interpretation of the former subsidy formulation (RSA, 1991a). A working document issued in 1992 stated that "The state will finance social welfare services in the future in accordance with an approved welfare programme..." and the implementation date was set for 1 April 1992 (RSA, 1992:14).

A significant shift in welfare policy occurred with the adoption of the White Paper for Social Welfare in 1997. The developmental approach to welfare service delivery necessitated yet another change to the funding policies. Since the adoption of the White Paper, another three funding policies were formulated. The first and fairly substantive, entitled Policy for Financing of Developmental Social Services, was issued by the national Department of Welfare in draft form only in May 1998. It identified four main categories of service; empowerment, community intervention, residential intervention and resource development, and planning and management (RSA, 1998:19). It is not known why this policy was not adopted or what the costs of its development were - anecdotal evidence suggests a very expensive exercise.

Instead, yet another financing policy was hastily prepared and gazetted in March 1999 for implementation on 1 April 1999. This policy identified four categories of service; prevention, early intervention, statutory process and continuum of care and developmental services (RSA, 1999:12-13). Ironically, this policy was based on tenets not that dissimilar to the policy of 20 years ago that also propounded prevention, community care and as last resort, institutional care and treatment (RSA, 1985:103). The 1999 policy focussed mainly on families, communities, children, youth, women and older persons. While adopted, it was never fully implemented and thus necessitated the continuation of the social work-based subsidy scheme. In, for instance in the Western Cape, the Department of Social Services for a number of reasons found it impossible "...to implement any aspect of the new policy with effect from April 1999." (RSA, 1999a:3). Some organisations suffered substantial financial loss by embracing the new policy without realising that their subsidy would continue to be determined by the old rather than the new policy. For example, by concentrating on prevention rather that providing residential care, their headcount, on which the former policy was based, dropped and so as a consequence the subsidy decreased.

Alas, this policy too did not survive. The Portfolio Committee on Welfare and Population Development was not consulted before adoption of the policy and at a briefing on the policy held on 27 October 1999, unanimously resolved “... that the failure to actually consult the committee on the Financing Policy was extremely unfortunate.” (RSA, 1999b:1). At the briefing, Ntjantja $\mathrm{Ned}$, the then deputy Director-General of Department of Welfare, agreed "...that the policy was a political document..." and that "The implementation of such an optimistic and ambitious policy would undoubtedly be difficult to say the least." (RSA, 1999b:1). Further, Selwyn Jehoma from the Financial and Fiscal Commission (FFC) stated that "He was convinced that the new Financing Policy needed a rethink taking into account the cost implications and strategies." (RSA, 1999c:1). 
Aldous Huxley [Themes and Variations] did warn, "The horror no less than the charm of real life consists precisely in the recurrent actualisation of the inconceivable". Yet another funding policy! Enter the newest policy, the Policy on Financial Awards to Service Providers 2004. Approved in February 2004 for implementation on 1 April 2005, “...this policy looks more broadly at the funding of services... [w] hereas the previous strategy looks only at social workers salaries... It has the objectives of transformation of NGO service delivery as well as the way they are funded. The policy seeks to promote accountability and good governance.” (RSA, 2005:23).

This policy introduces new concepts; there are transformation and performance criteria the beneficiary organisations will have to meet. Seemingly, most of the respondents are of the opinion that they will meet these requirements. Out of 228 responses, only $118(52 \%)$ organisations indicated an awareness of the new policy and 102 had read it. Of these, $76(74 \%)$ were of the opinion that they would comply with the transformation requirement and $190(84 \%)$ out of 226 responses, indicated that their service programmes were designed with adequate controls (measurable outcomes) while 154 (76\%) were satisfied that their service programmes were achieving the desired outcomes.

Will this new policy survive? The policy in its present form is unacceptably vague and the supporting documents required for successful implementation (procedure manuals, norms and service standards, key performance indicators, among other) are seemingly not yet available. Ominously, at the Portfolio hearings on the 1999 policy, Selwyn Jehoma said, “...that when formulating policy, one should have clear implementation guidelines, which were simply absent... [and suggested in the case of that policy]...that it was necessary to go back to the drawing board." (RSA, 1999c:1). Similar to widespread complaints at the lack of consultation for the 1999 policy, only $36(16 \%)$ organisations indicated that they were consulted in the drafting of the new policy - this despite consultation being the first principle of Batho Pele (RSA, 1997:15).

Thus, despite the enterprising initiative of some seven decades ago when social workers were first subsidised, the countless funding policies issued since then and the last 20 years of programme funding talk, ominously little progress has been made. As such, permission is sought to alliterate the country's numerous and ever-changing funding policies. In Greek mythology, Proteus, the son of Oceanus and Tethys was an early sea god or the oracular "Old Man of the Sea" as Homer referred to him in the Odyssey. He was famed for his constant changing - he personifying changeability, variation, vacillation and inconsistency. Among other, twenty years of protean funding policies have taken its toll on the private welfare sector.

Also alarming is the astronomical cost of developing all these failed policies. With the introduction of each policy there are the endless and costly road shows replete with victuals and bonhomie to introduce them. Over the years, the sales pitch and spin increased progressively in an attempt to counteract the ever-growing incredulity in the circus tent. Not to mention all the strategic planning meetings, bosberade, lekgotlas and more lately the imbizos. Who benefits the most? Not the poor, rather officialdom and the ubiquitous catering, travel and paper industries.

However, despite repeated attempts at introducing a fully functioning programmed-based funding policy, welfare organisations are still receiving subsidies based on the former policy. It is against this backdrop that welfare organisations have had to develop survival strategies in order to survive a ruthless reality. Are organisations sufficiently sagacious and do they have the requisite political nous and financial acumen to survive this funding volatility? 


\section{PROFILE OF BENEFICIARY ORGANISATIONS}

The annual funding application process for the Community Chest was completed by 185 (79\%) persons employed by the organisation debunking the myth that volunteers are responsible for this task. Of concern though is the low number of these that recorded qualifications in bookkeeping/accountancy - 76 had a matric or lower bookkeeping qualification while only 28 had post matric qualifications in accounting with only 6 of these indicating registration with one of the three accounting professional bodies (South African Institute of Chartered Accountants, South African Chartered Institute of Secretaries and the Institute for Commercial and Financial Accountants).

The annual budget preparation was done by a bookkeeper/accountant in $76(33 \%)$, a committee in $63(27 \%)$, the director in $10(4 \%)$, a group of people in $59(25 \%)$ and "other" in $25(11 \%)$ cases respectively. Knowledge of budgeting is of concern. The majority, 131 (59\%) indicated that zerobased budgeting is not well understood and only $68(30 \%)$ indicated that they had developed a zero-based budget in the last five years. Given that the concept of programme funding has been around for more than twenty years, $79(36 \%)$ organisations still used the elementary line-item budget whereas only 59 (27\%) used a programme budget and even fewer (45 or 20\%) used the more effective form of budgeting, the functional budget. Worryingly, 37 (17\%) could not identify the budget format that they employed.

The majority of respondents, 130 (58\%) were not familiar with Section 38(j) of the Public Finance Management Act, 1999 (Act 1 of 1999) while only 80 (35\%) were familiar with the King Commission on good governance. Mind-bogglingly, only $44(21 \%)$ respondents indicated that the fiduciary responsibilities of management boards were clearly understood by board members. While $95(42 \%)$ organisations were committed to the code of conduct formulated by the South African Grant Makers Association and/or the Charities Aid Foundation, the majority or 108 (48\%) did not know whether or not they were.

These results are not assuring. On the contrary, it reflects a lack of financial acumen that is so much needed in order to partly neutralise the state of flux that exists in welfare funding.

\section{SUSTAINABILITY AND DEVELOPMENT}

The situation becomes more foreboding. When asked whether the organisation's future was very secure, $157(68 \%)$ said no. Of these, 123 (75\%) indicated that this was due to a lack of funds. Despite the need for more services and an expansion of existing services, 205 (89\%) organisations intimated that their organisation's further growth was constrained by a lack of funds.

A hundred and thirty-five $(60 \%)$ organisations indicated that the amount of funding they received from the government (all sources) had declined as a percentage of income over the past few years. An extraction of data (audited financial statements for 1999-2004) from the Community Chest organisation database for all beneficiary organisations alarmingly reflects the overall decline in subsidy as a percentage of expenditure, but particularly so for rural areas where poverty levels are highest - see Table 1 . 
TABLE 1

DECLINE IN SUBSIDY INCOME AS PERCENTAGE OF EXPENDITURE

\begin{tabular}{|c|c|c|c|c|c|c|c|}
\hline Year & $\begin{array}{l}\text { Rural } \\
\text { Subsidy }\end{array}$ & Expense & $\%$ & $\begin{array}{c}\text { Urban } \\
\text { Subsidy }\end{array}$ & Expense & $\%$ & $\begin{array}{l}\text { Rural/ } \\
\text { Urban } \\
\% \\
\end{array}$ \\
\hline 1999 & $11,610,658$ & $21,830,641$ & 48.71 & $54,793,393$ & $155,703,433$ & 33.84 & 37.40 \\
\hline 2000 & $12,263,907$ & $23,838,455$ & 31.79 & $52,152,144$ & $161,908,612$ & 29.79 & 34.68 \\
\hline 2001 & $16,951,419$ & $38,578,130$ & 41.92 & $66,673,232$ & $175,047,245$ & 36.05 & 39.15 \\
\hline 2002 & $19,124,915$ & $40,435,259$ & 43.90 & $73,746,070$ & $184,930,878$ & 33.78 & 41.21 \\
\hline 2003 & $20,455,302$ & $43,563,769$ & 42.91 & $78,046,079$ & $218,288,034$ & 32.41 & 37.62 \\
\hline \multirow[t]{3}{*}{2004} & $20,840,182$ & $47,667,243$ & 43.72 & $86,043,182$ & $240,827,230$ & 35.73 & 37.05 \\
\hline & \multirow{2}{*}{\multicolumn{2}{|c|}{$\begin{array}{l}\text { Average } \\
\text { Increase/decrease }\end{array}$}} & 42.16 & & & 33.60 & 37.85 \\
\hline & & & -4.99 & & & 1.89 & -0.35 \\
\hline
\end{tabular}

Similarly, $172(76 \%)$ indicated that in relation to escalating costs, the annual grant from the Community Chest got smaller every year. Further, 199 (91\%) indicated that their organisations were concerned that the annual amount the Community Chest collected for distribution did not increase sufficiently to meet existing needs. One hundred and fifty-nine (71\%) respondents indicated that if the Community Chest did not significantly raise its income it would become irrelevant in a few years time. This would eliminate one of the oldest and most trusted funding agencies in the Western Cape. Understandably thus, $136(66 \%)$ organisations wanted the Community Chest to deal more aggressively with its competitors.

Compounding the situation is the difficulty in securing operational funding. One hundred and ninety-one $(84 \%)$ organisations indicated that funding for capital projects was more readily available than was funding for operational expenditure and staggeringly, 212 (94\%) indicated that fundraising for operational expenditure was the most difficult of their organisation's fundraising activities. In most cases, only two funders were prepared to fund operational expenditure. Anecdotally, this puts much more reliance on state subsidy and Community Chest funding - both annually declining as a percentage of expenditure.

Given the financial austerity alluded to, it is surprising that organisations have not improved their fundraising ability - only $45(20 \%)$ considered their ability to be excellent or very good. Table 2 contains the respondents' ability to raise funds.

TABLE 2

ORGANISATION'S ABILITY TO RAISE FUNDS $N=232$

\begin{tabular}{|l|rl|}
\hline Excellent & 1 & $(1 \%)$ \\
\hline Very Good & 44 & $(19 \%)$ \\
\hline Average & 142 & $(61 \%)$ \\
\hline Poor & 37 & $(16 \%)$ \\
\hline Very poor & 8 & $(3 \%)$ \\
\hline
\end{tabular}


Of the 'average, poor, very poor' responses, the most common causes cited were lack of funding sources, no fundraising staff and too much competition for funds. Another surprise, given the contents of Table 2, was that $118(51 \%)$ organisations indicated that they had received training in fundraising. Further, only $34(15 \%)$ received training from the Southern African Institute of FundRaising (SAIF) and only $37(16 \%)$ were members of SAIF. Only $11(6 \%)$ non-members attended SAIF meetings. Interestingly, of the $196(86 \%)$ respondents that indicated that the Community Chest should provide more training, $169(86 \%)$ requested training in fundraising and $141(72 \%)$ in marketing. Clearly organisations are acutely aware of the importance of these two functions for survival.

Financial vulnerability was clearly reflected with only $71(32 \%)$ organisations having had a policy on financial reserves and in the case of organisations that were affiliated to parent bodies (122 or $55 \%$ of the respondents) only $31(25 \%)$ had a formal agreement with the parent body to cover potential annual financial shortfalls.

\section{Funding strategies}

A funding strategy (or fundraising strategy) is the strategy formulated to source and maintain sufficient income to meet current and projected revenue needs. Cook (2002:291) states that while "The goal of fundraising is to obtain the necessary resources to carry-out your organisation's mission. A fundraising strategy is a carefully structured, well-researched plan to gain those resources for your organisation". It is aimed at improving survival chances and as such should according to Cook (2002:296-300) include diversification (many sources of income), sustainability (self-reliance), creativity (initiative and risk taking) and inclusiveness (role for various supportive people). What strategies have the respondents developed in order to survive the ruthless reality?

Firstly, $167(72 \%)$ organisations did not have a marketing plan and only $82(36 \%)$ had a database of funding sources. Only $10(4 \%)$ thought that there was an increasing threat that their organisation's service will in future be provided by a for-profit (business) organisation. This reflects ignorance of the growth of this threat as funding policies now make provision for such an eventuality. The opportunity to raise funds through operating a business was also not exploited only $17(8 \%)$ operated a registered 'for profit' business organisation to generate profits as a source of income. Of those who did not operate a business, 91 (47\%) rejected assistance in creating such and organisation.

Further, only $39(17 \%)$ employed a fundraiser while the majority, $104(45 \%)$ relied on a committee, $36(16 \%)$ relied on individual staff members and $22(10 \%)$ on the director to raise funds respectively. Alarmingly, $158(68 \%)$ indicated that direct service professionals (social workers, teachers, etc) were sometimes expected to spend time on fundraising thus precluding them from providing the needed professional practice. This is both costly and counterproductive.

\section{SOURCES OF REVENUE}

In addition to state funding, other sources of funding such as funding agencies and the corporate sector are no less capricious. Increasingly, corporate donors are selecting their own projects to fund directly. This development was confirmed by $162(70 \%)$ organisations and of these, 109 $(61 \%)$ indicated that this threatened their organisation's existence. Further, in Table 3 it is clear that the most difficult sectors to secure funding from are the corporate sector $120(55 \%)$ followed by the government $52(24 \%)$ and the Lotto $37(17 \%)$. 
TABLE 3

ORGANISATIONAL DIFFICULTY IN ACCESSING FUNDS $N=216$

\begin{tabular}{|l|rl|}
\hline Government & 52 & $(24 \%)$ \\
\hline Community Chest & 3 & $(1 \%)$ \\
\hline Corporates & 120 & $(56 \%)$ \\
\hline Lotto & 37 & $(17 \%)$ \\
\hline Other & 4 & $(2 \%)$ \\
\hline
\end{tabular}

The South African National Lottery was founded in 1999 in terms of the National Lottery Act, 1997 (Act 57 of 1997). Its flagship, the Lotto, has been controversial since its inception. Apart from interminable delays in distributing funds there has been widespread criticism. According to Louw (2002:20) "In the 2001-2002 funding cycle, barely half (R233million) of the money available (R439 million) was dispersed. This is a national disgrace, and cannot be allowed to continue." Further, Louw stated that there is a lack of "...any clear developmental agenda informing the allocation of funding..." and that as a result of the potential to change criteria for priority funding "...organisations can (and, in the case of Charities, have already) find themselves in a situation where they have to "reinvent" themselves annually in order to apply for funding." (Louw, 2002:21).

Currently, while 157 (68\%) organisations indicated that they received funds from the National Lottery, 133 (61\%) were not happy with the manner in which the funds were distributed. The single biggest cause for unhappiness was the uncertainty of funding ( 75 or $56 \%$ ) followed by too lengthy a process (63 or 47\%). The cumulative responses for this unhappiness are juxtaposed with those recorded for the National Development Agency (NDA) in Table 4. It could be argued that in contrast to the disgruntlement with the Lotto, the credibility enjoyed by the Community Chest resulted in $169(74 \%)$ organisations that wanted the Lotto to annually award a global amount for the Community Chest to allocate.

Once again, the imperial intention dictated a centralised, statutorily determined national lottery which resulted in the demise of the very profitable scratch card operations pioneered by the Community Chest of the Western Cape and adopted by among others, the Viva and Ithuba Trusts. This removed from the non profit sector the ability to design and operate lottery activities and thus the right to resource allocation decision making. In terms of the Act, 'Charities' must compete with four other categories for funds. With the introduction of scratch cards, the Community Chest nearly doubled its funds for allocation - income now lost to this funding agency despite its sophisticated and trusted allocation system and repeated assurances that the National Lottery will make good such losses.

Established in 1998 in terms of the National Development Agency Act, 1998 (Act 108 of 1998) as a public entity listed under schedule 3A of the Public Finance Management Act, 1999 (Act 1 of 1999), the NDA reports to Parliament through the Minister of Social Development. It was established among other to, “...grant funds to Civil Society Organisations (CSOs) for the purpose of meeting the developmental needs of poor communities; [and to]...strengthen the institutional capacity of CSOs for long term sustainability..." (RSA, 2005a:7). Given its establishment some seven years ago, its mandate to assist the poor and its accountability to Parliament through the Minister of Social Development, it is very worrying that a mere $23(10 \%)$ out of the responding 231 organisations indicated that they received funding from the NDA. Even more worrying is that 
the vast majority of the Community Chest's beneficiary organisations serve poor communities. It is therefore not surprising that a staggering $92(91 \%)$ out of the 101 organisations that responded to a question about their happiness with the manner in which the NDA distributed its funds indicated that they were not happy for reasons listed in Table 4.

TABLE 4

REASONS FOR UNHAPPINESS WITH LOTTO AND NDA DISTRIBUTION OF FUNDS

\begin{tabular}{|c|c|c|}
\hline & LOTTO $n=133$ & NDA $n=92$ \\
\hline Allocated less than requested46 (36\%) & & $(0 \%)$ \\
\hline Funding criteria unclear & $(28 \%)$ & $(59 \%)$ \\
\hline Process too lengthy & $(47 \%)$ & $(36 \%)$ \\
\hline Disagree with funding criteria & $(14 \%)$ & $22 \quad(23 \%)$ \\
\hline Process too cumbersome & $17 \quad(13 \%)$ & $(32 \%)$ \\
\hline Uncertainty of funding & $75 \quad(56 \%)$ & $37 \quad(40 \%)$ \\
\hline Political/other interference & $(0 \%)$ & $(1 \%)$ \\
\hline Other & $21 \quad(16 \%)$ & $24 \quad(26 \%)$ \\
\hline Delayed payment & $46 \quad(36 \%)$ & \\
\hline Infrequency of award & $(14 \%)$ & \\
\hline Welfare sector allocated too little & $(45 \%)$ & \\
\hline Centralisation of process & & $(1 \%)$ \\
\hline NDA Governance issues & & $37 \quad(40 \%)$ \\
\hline
\end{tabular}

Yet another centrally controlled source of funding that from this survey appears not to be responding to needs and attracts much disgruntlement - another imperial intention?

\section{FUTURE FUNDING OPTIONS}

When asked whether the organisation spends too much time (in relation to time spent on providing the service) in developing various funding applications each year, 93 (41\%) indicated in the affirmative. Further, $124(54 \%)$ of respondents indicated that they would prefer to submit one application to one organisation for all their funding (including national/provincial/local government and all other funders like the Community Chest, Lotto, etc). One hundred and fiftyone $(66 \%)$ organisations wanted the Community Chest to act as a broker on their behalf to acquire funds from international funding agencies.

Given the poor record of fundraising, surprisingly the majority of organisations (142 or 63\%) indicated that they did not want to diminish their fundraising capacity and rely on one organisation to do this. The vast majority of the balance $83(37 \%)$ that were prepared to do so were also prepared to pay a brokerage of some ten percent.

One hundred and thirty five (58\%) organisations had access to Microsoft Exel and 137 (59\%) had the expertise to submit their funding applications electronically. Of those that did not have the expertise (94 or $41 \%), 89(87 \%)$ indicated that they wished to acquire such expertise.

In what appears to be a lack of welfare leadership in the Western Cape, an overwhelming 180 (81\%) organisations wanted the Community Chest to provide leadership in determining the funding needs of the region and attempt to influence funding policies based on these needs. Further, in what appears to be a lack of effective needs analysis for funding in the Province (or a 
distrust of that which does take place), a hefty $186(81 \%)$ indicated that the Community Chest should facilitate an annual needs analysis for the region that will include all stakeholders to better target the most needy services. A similarly large number, 204 (87\%) wanted the Community Chest to provide regular information sessions on the priorities it has identified for funding in terms of the said needs analyses.

This is not surprising given the high levels of credibility that the Community Chest enjoys locally. One hundred and ninety three $(84 \%)$ organisations stated that membership of the Community Chest added credibility to their organisations. Further confidence in the organisation was reflected in the $171(86 \%)$ organisations that indicated that the Community Chest had a very sophisticated allocation procedure while $211(98 \%)$ indicated that it could be trusted to make the right allocation decisions.

The design of the Community Chest's financial resource allocation decision making process is both innovative and complex. It has superlative data generating capabilities that can provide very sophisticated patterns of service needs, financial management, sources of funding and service outputs. It can also generate a wide variety of financial and service performance norms. While it has the credibility and support mentioned previously, the expertise, the wherewithal, it is in Rand terms one of the smaller funding agencies. It is however capable of disbursing far larger sums of money in a far more accurate and targeted manner than most of its counterparts can.

It is not inconceivable that all submissions for funding could be submitted electronically (via internet, email or other media) to one organisation that can broker the required income needed from all sources, including state subsidies. A one-stop funding process will bring together need and funding in a more effective and rational manner. Given intuitive leadership and entrepreneurial flair, this could conceivably become an innovative imperial intention that unlike the others is more fervently embraced.

\section{CONCLUSION}

Each year the county's need for social services shows remarkable growth. Not surprisingly, the industry that is supposed to address these rising needs will not be outdone. It too, has shown remarkable growth and so have its policies and endless deliberations. Yet, there is a distinct disjuncture between these growth patterns. The industry growth is supposed to curtail the service need growth yet anecdotal evidence suggests exactly the opposite.

If this country is serious about helping the poor it needs to nurture and support rather than destroy the more capable and motivated private welfare sector. As evidenced in this paper, this sector faces major financial difficulties partly as a result of poorly conceived and executed policies. But the private welfare sector is not without blemish either. Its inability to better secure itself despite all the strategic planning sessions it and government welfare staff are forever attending cannot be blamed on government.

It is time to purge the welfare parchment on which this ruthless reality is etched, a lamentable chronicle of piteous policies, consummate confusion and lacklustre leadership. South Africa must abandon its dysfunctional, albeit colourful, patchwork quilt of welfare activities and return to a clean canvass. Here it needs to more accurately sketch need, better formulate policy and construct a more responsive welfare empire where all contributors are both enabled and supported in their common quest to serve the poor. The state/private welfare partnership of yore, then ill-intentioned or not, can still be a powerful force for good if both parties are equally yoked and importantly, in agreement on the fields to be ploughed, the performance parameters and the resources required. 
As previously stated, ominously little progress has been made in improving funding policies since social workers were first subsidised some seven decades ago. Welfare organisations have also not sufficiently adapted to the changing financial environment in which they operate. But why is there this lack of progress? Decades ago George Bernard Shaw [Maxims for Revolutionists] stated that "The reasonable man adapts himself to the world: the unreasonable one persists in trying to adapt the world to himself. Therefore all progress depends on the unreasonable man." Is this the answer; are social workers and their ilk just too reasonable?

\section{REFERENCES}

COOK, K. 2002. Proposal writing and fundraising. A guide for South African nongovernmental organisations and community-based organisations. Cape Town: South Coast Foundation.

LOUW, S. 2002. Smoke and mirrors? The National Lottery and the non-profit sector. Research Report 1. Durban: University of Natal, Centre for Civil Society.

MARTINE, L. 1989. Subsidies for social work in South Africa - progress and potential. Maatskaplike Werk/Social Work, 25(2):123-128.

MCKENDRICK, B.W. 1985. Programme proposals in South African welfare planning. Maatskaplike Werk/Social Work, 21(3):157-174.

REPUBLIC OF SOUTH AFRICA 1985. Verslag oor 'n Ondersoek na die huidige Welsynsbeleid in die Republiek van Suid-Afrika en die Staat se Aandeel in die Finansiering van Welsynsdienste. Pretoria. Departement van Staatkundige Ontwikkeling en Beplanning: Direktoraat Maatskaplike Beplanning.

REPUBLIC OF SOUTH AFRICA 1987. Circular 10/1987 (undated). Pretoria. Department of Social Welfare.

REPUBLIC OF SOUTH AFRICA 1991. Voluntary Welfare Initiative and the Financing of the Welfare System. Pretoria. Department of National Health and Population Development.

REPUBLIC OF SOUTH AFRICA 1991a. Circular, 57/1991 (1 November). Department of National Health and Population Development, Administration. Pretoria: House of Assembly.

REPUBLIC OF SOUTH AFRICA 1992. Points of Departure in Developing a new Social Welfare Dispensation for the RSA. Pretoria. Department of National Health and Population Development, Administration: House of Assembly.

REPUBLIC OF SOUTH AFRICA 1997. Government Gazette, Vol. 388 No. 18340 (1 October). Pretoria: Government Printer.

REPUBLIC OF SOUTH AFRICA 1998. Draft Policy for the Financing of Developmental Social Welfare Services. Pretoria: Government Printer.

REPUBLIC OF SOUTH AFRICA 1999. Government Gazette, Vol. 405 No. 19888 (29 March). Pretoria: Government Printer.

REPUBLIC OF SOUTH AFRICA 1999a. Circular, 1/99 (5 February).Western Cape: Provincial Administration Western Cape: Department of Social Services.

REPUBLIC OF SOUTH AFRICA 1999b. Parliamentary Monitoring Group. Portfolio Committee on Welfare and Population Development. Briefing on Welfare Financing Policy, 27 October 1999. Available: http://www.pmg.org.za/ 
REPUBLIC OF SOUTH AFRICA 1999c. Parliamentary Monitoring Group. Portfolio Committee on Welfare and Population Development. Briefing on Welfare Financing Policy, 12 November 1999. Available: http://www.pmg.org.za/.

REPUBLIC OF SOUTH AFRICA 2004. Policy on Financial Awards to Service Providers. Pretoria. Department of Social Development.

REPUBLIC OF SOUTH AFRICA 2005. Strategic Plan 2005-2009. Cape Town. Provincial Administration Western Cape. Department of Social Services and Poverty Alleviation.

REPUBLIC OF SOUTH AFRICA 2005a. Strategic Plan 2005/06 to 2009/10. Pretoria: National Development Agency.

WINCKLER, A.T. 1969. Volkswelsynsbeleid. Stellenbosch: Kosmo-Uitgewery Edms Bpk.

Professor André de V Smit, Department of Social Development, University of Cape Town, Cape Town, South Africa. 